\title{
Landslide and debris flow in the Himalayas: A case study of the Madi Watershed in Nepal
}

\author{
Narendra R Khanal†* and Teiji Watanabeł \\ † Central Department of Geography, Tribhuvan University, Kirtipur, Kathmandu, NEPAL \\ ¥ Laboratory of Geoecology, Graduate School of Environmental Earth Science, Hokkaido University, Sapporo 060-0810, JAPAN \\ *To whom correspondence should be addressed.E-mail:nrkhanal@geo07.ees.hokudai.ac.jp
}

Landslides, debris flow and other forms of mass wasting are common in mountain areas. These are the main geomorphic processes which are responsible for the transformation of landforms not only the mountain slopes but also the valleys, plains and river channels far downstream. Such transformation because of frequent occurrences of landslides and debris flow is very pronounced in the Himalayas with high energy environment due to active tectonics, rugged topography with very high relief and highly concentrated monsoon precipitation. Moreover, high density of both human and livestock population and consequent change in land use and land cover have caused further intensification of the processes of landslide and debris flow occurrence. The loss of life and properties from landslide, debris flow and flood has been increasing and the livelihood options of mountain people have been threatening.

This paper aims to discuss i) temporal and spatial distribution of landslide and debris flow ii) its causes iii) dynamics in terms of stability and iv) vulnerability and mitigation issues. This is a case study done in the Madi watershed. Major sources of information for this study are air photographs taken in different periods - 1956/58, 1972, 1979 and 1996 and discussions with local people. Field verification of the information derived after the interpretation of air photographs and group discussions in many places in the watershed were carried out during field work in 1999/2000.

The Madi watershed with an area of $1123 \mathrm{sq} \mathrm{km}$ and population of about 0.2 million is located in the Western Development Region of Nepal. The altitude of the watershed ranges from $307 \mathrm{~m}$ in the south to $7937 \mathrm{~m}$ in the north encompassing three major physiographic regions - the middle mountain, the high mountain and the high Himalaya. It comprises three major geological formations - the Lesser Himalayan meta-sediments in the south, the Higher Himalayan crystalline and Tibetan sedimentary Tethys sediment in the north. The Lesser Himalayan consists of intensely folded metasedimentary rocks whereas the Higher Himalayan crystalline consists of Precambrian high grade metamorphic rocks. The Main Central Thrust (MCT) crosses in the east-west direction in the central part of the watershed. The topography is very rugged. Gently sloping land $\left(<5^{0}\right)$ comprises only 9 percent of the total basin area followed by moderately to steeply sloping $\left(5-30^{\circ}\right)$ mountain terrain and very steeply sloping $\left(>30^{\circ}\right)$ mountain terrain with rock headwalls. The average annual precipitation ranges from $1795 \mathrm{~mm}$ in the south to $3743 \mathrm{~mm}$ in the northwest. The average number of rainy days is between 130-180 days per year. More than 70 percent of the total precipitation occurs in four summer months (June-September). Daily precipitation with more than $100 \mathrm{~mm}$, which causes slope instability (Caine and Mool 1982), occurs frequently in the watershed. The area is inhabited by more than 16 ethnic groups. The livelihood of most of people is based on natural resources and agriculture is the main occupation.
TABLE 1. Area covered by air photographs (sq km) and number and density (no/100 sq km) of landslide and debris flow scars in different periods in the Madi watershed

\begin{tabular}{llllll}
\hline Year & Area & $\begin{array}{l}\text { Total } \\
\text { number }\end{array}$ & New & $\begin{array}{l}\text { Active/ } \\
\text { reactivated }\end{array}$ & Density \\
\hline $1956 / 58$ & 998.1 & 236 & na & 236 & 23.6 \\
\hline 1972 & 481.0 & 18 & 5 & 13 & 3.7 \\
\hline 1979 & 744.5 & 5 & 1 & 4 & 0.7 \\
\hline 1996 & 1123.5 & 25 & 15 & 10 & 2.2 \\
\hline
\end{tabular}

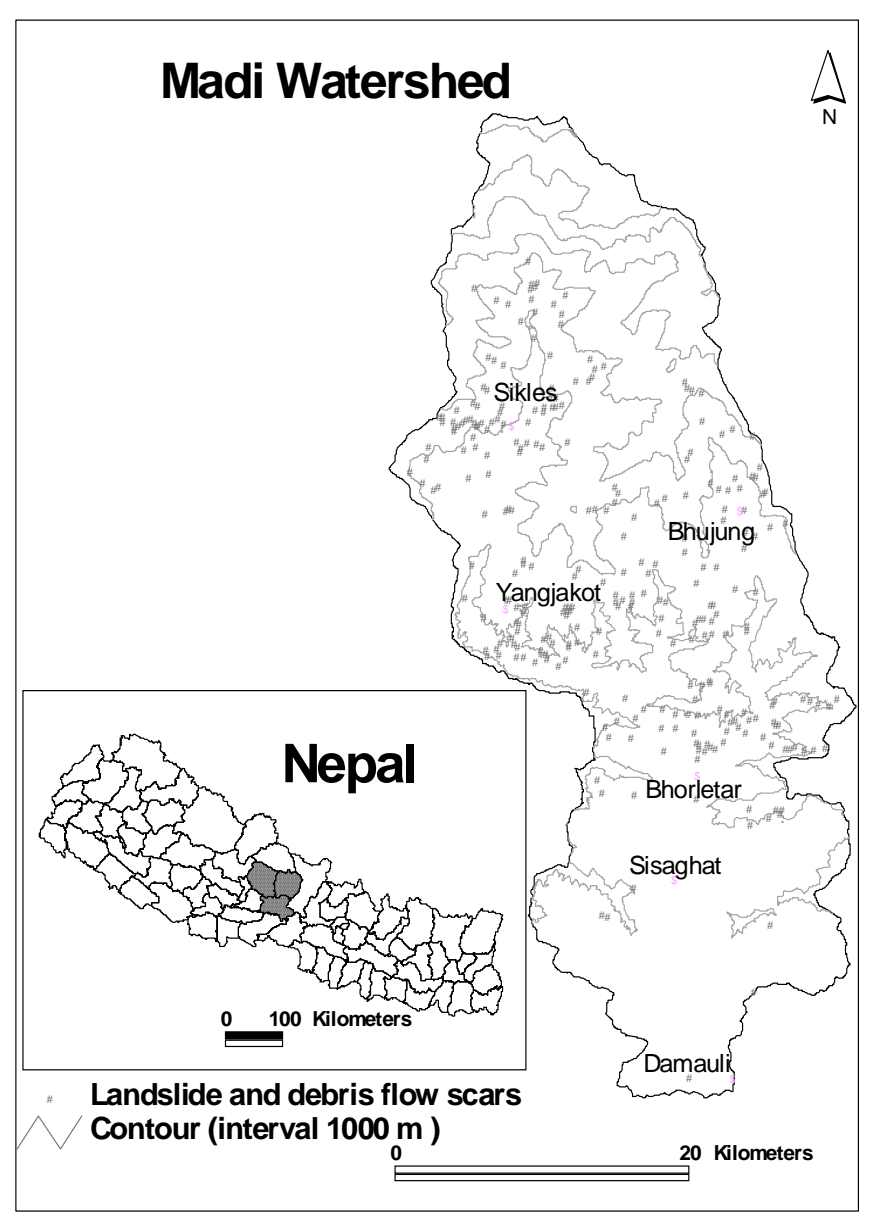

FIGURE 1. Distribution of landslide and debris flow scars in the Madi watershed 
A total of 236 active landslide and debris flow scars were identified in air photographs taken in 1956/58, 18 in 1972, 5 in 1979 and 25 in 1996 in the Madi watershed. Direct comparison of the number of landslide and debris flow scars for this watershed is not possible due to unavailability of air photographs covering the whole watershed for all the periods. In order to compare the results, density of landslide and debris flow scars has been calculated and presented in Table 1 . The density of landslide and debris flow scars declined from about 24 per 100 sq $\mathrm{km}$ in 1956/58 to 4 in 1972, one in 1979 and 2 in 1996. These landslide and debris flow scars were concentrated mainly in five localities namely Siklesh, Saimarang, Bhujung, Karapu and Jita area (Figure 1).

Large numbers of landslide and debris flow scars were initiated in between 1948-1955 in many parts of the watershed due to heavy precipitation though the volume and intensity of those events were not recorded. Rivers were blocked for few hours by the logs and sediment several times particularly at the confluence point of two major rivers and narrow sections of the channel resulting drastic change in the morphology of both the channels and flood plains even far downstream areas during this period. Many of the landslide and debris flow scars identified in photographs taken in 1956/58 were small and shallow. Initiation of many small and shallow landslide and debris flow scars during and after highly localized heavy precipitation events like in the Madi watershed in between 1948-1955 has also been reported from other areas of Nepal in recent years (Manandhar and Khanal 1988, Dhital et al. 1993, Upreti and Dhital 1983, Khanal 1998). Some of the landslide and debris flow scars were initiated during the earthquake of 1934 and some were initiated later along the MCT. Many of them are located between 500 and 2500 $\mathrm{m}$ in altitudes, on southern aspect and shrub land. Some of them are located in remote areas far from human settlement affecting down stream landforms and hydrology. A few on upper slopes were initiated even in winter period (Feb-March) due to the melting snow and ice. Factors such as tectonic activities, climate, topography, river hydrology and land use/land cover play important role in the initiation and enlargement of landslide and debris flow scar in the watershed.

Many of the small and shallow landslide and debris flow scars were stabilized in a few years after their occurrence. Many of them were stabilized naturally and some of them were stabilized through the efforts of local community. However, large landslide and even the small one located along the gullies and river course are expanded and reactivated from time to time. Out of a total of 25 landslide and debris flow scars identified in air photographs taken in 1996, 10 were initiated before 1956/58 and remaining 15 were occurred between 1979 and 1996.

Landslide and debris flow events in between 1948-55 damaged large area of agricultural land and threatened many settlements in the watershed. As a result large scale outmigration took place from those areas which were affected most by landslides and floods. The damages from landslide, debris flow and flood events during this period remained very high not only in this watershed but in many parts of the country. As a response, the government started resettlement program in the Inner Terai and Terai regions of Nepal for families severely affected by landslide and debris flow immediately after the events of 194855. The loss of life and properties from landslide and debris flow remained very high also in 1976, 1983 and 1998 in this watershed. One landslide and debris flow at Paire swept away 90 people including hotel owners and travelers rested there in 1976. Landslide and debris flow of 1983 killed seven people at Tandrang Taksar and that of 1998 displaced many families at Saimarang.

Human settlements in the watershed have been threatened due to reactivation and enlargement of old landslides. Six major settlements are in immediate danger from active landslide. Some of these landslides were very small at the initial stage and could be controlled through local efforts. But now some of them are very big and it is beyond the capability of local people to control them and the only way to reduce the loss is to abandon the area. The landslide initiated before 1954 in Taprang was reactivated in 1979. It is being enlarged every year threatening the livelihood options of more than 305 families residing in Taprang. Many families have already been migrated to other places due to danger of landslide. Similar situation is found in other areas such as Chautha, Saimarang, Bhoje and Gobinderi in the Madi watershed.

Though local people are aware about the problem of landslide still landslide control and management activities in organized way have not received priority yet. Moreover, the community based natural resource management and disaster mitigation systems of the past have been eroding. As a result, the vulnerability of life and properties in the area has been increasing. It requires effective landslide and debris flow control activities in an organized way with active participation of local people in order to minimize the loss of life and properties. These community based institutions should be strengthened with provision of training and other necessary supports.

\section{Acknowledgements}

Authors would like to acknowledge financial support provided by ICIMOD for fieldwork and Forest Survey Division and Topographical Survey Division for providing air photographs taken in different periods.

\section{References}

Caine N and PKMool. 1982. Landslides in the Kolpu Khola drainage, middle mountains, Nepal. Mountain Research and Development 2(2): 157-173

Dhital M, N Khanal and KB Thapa.1993. The role of extreme weather events, mass movements, and land use changes in increasing natural hazards. A report of the preliminary field assessment and workshop on causes of the recent damage incurred in south-central Nepal (July 19-20, 1993), Kathmandu: ICIMOD

Khanal NR. 1998. Study of landslide and flood affected area in Syangja and Rupandehi districts of Nepal. A report submitted to Mountain Natural Resources' Division, International Centre for Integrated Mountain Development (ICIMOD), Kathmandu, Nepal

Manandhar IN and NR Khanal. 1988. Study on landscape processes with special reference to landslides in Lele watershed, Central Nepal. A report submitted to Research Division, Tribhuvan University, Kathmandu, Nepal

Upreti BN and MR Dhital. 1996. Landslide Studies and Management in Nepal. Kathmandu: ICIMOD 